\title{
Barbaro Pietro Vaccaro, Lohengrin, fils de Parsifal
}

\section{Ida Merello}

\section{(Q) OpenEdition}

\section{Journals}

\section{Edizione digitale}

URL: http://journals.openedition.org/studifrancesi/9009

DOI: 10.4000/studifrancesi.9009

ISSN: 2427-5856

\section{Editore}

Rosenberg \& Sellier

\section{Edizione cartacea}

Data di pubblicazione: 1 octobre 2008

Paginazione: 485

ISSN: 0039-2944

\section{Notizia bibliografica digitale}

Ida Merello, «Barbaro Pietro Vaccaro, Lohengrin, fils de Parsifal», Studi Francesi [Online], 155 (LII | II) |

2008, online dal 30 novembre 2015, consultato il 10 janvier 2021. URL: http://

journals.openedition.org/studifrancesi/9009 ; DOI: https://doi.org/10.4000/studifrancesi.9009

Questo documento è stato generato automaticamente il 10 janvier 2021.

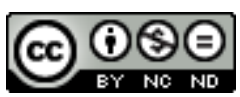

Studi Francesi è distribuita con Licenza Creative Commons Attribuzione - Non commerciale - Non opere derivate 4.0 Internazionale. 


\title{
Barbaro Pietro Vaccaro, Lohengrin, fils de Parsifal
}

\author{
Ida Merello
}

\section{NOTIZIA}

BARBARO PIETRO VACCARO, Lohengrin, fils de Parsifal, Catania, CUECM, 2007, pp. 267.

1 Il volume, offerto anche in versione elettronica, prosegue il lavoro sulle concordanze dell'opera di Laforgue, iniziato con i testi poetici. Dopo une traduzione con testo a fronte del Lohengrin, seguita da una sventagliata di spigolature critiche, sia contemporanee all'opera che novecentesche, e una bibliografia essenziale, dove sono messe soprattutto in risalto le edizioni delle Moralités e le loro traduzioni, l'A. propone una tavola delle concordanze con tutte le occorrenze lessicali del testo, seguita da due liste di lemmi: una per frequenza e l'altra per categoria grammaticale, concluse da un quadro statistico. 